\title{
Challenges Faced by Large Mines in Botswana in the Development and Execution of Mine Closure Plans
}

\author{
K. Abi Department of Mines, Ministry of Minerals, Energy and Water Resources, Botswana
}

\section{INTRODUCTION}

This paper is intended to explore challenges faced by large mines in Botswana in planning and execution of mine closure plans. It identifies key issues and makes some suggestions as to how they may be addressed.

Large scale mining in Botswana has a positive legacy. The large mines have provided the much needed jobs, government revenues, business for linking industries and social investment in skills development, housing, health facilities and infrastructural development such as roads. The fact remains however that mining entails exploitation of finite resources and mine closures are inevitable.

Large mining companies in Botswana face challenges in the preparation and execution of mine closure plans which include:

- Inadequacy of environmental legislation to guide the companies.

- Inadequacy of environmental expertise to guide the mine closure process from planning to final closure.

- Meeting approval requirements of the authorities for the mine closure plans.

- Gaining acceptance of communities for the mine closure plans.

- Sustainability of Social investment programs by mining companies.

- Preservation of a positive legacy.

The suggested way forward in dealing with these challenges is for mining companies to:

- Establish environmental management systems and adopt sustainable development frameworks that meet international standards and norms.

- Take it upon themselves to develop environmental expertise including offering training opportunities for third parties.

- Involve communities intimately in the mine closure process so as to gain informed acceptance for mine closure plans.

- Develop integrated mine closure plans such that both the environmental and social issues are adequately addressed. This will minimise the adverse socio-economic impacts upon mine closure and in turn preserve a positive legacy for the mining company.

- Make their Social investment programs autonomous such that they can be sustained beyond mine life.

The authorities also have a challenge to expeditiously develop and consolidate the relevant legislation, develop capacity to effectively deal with mine closure issues and develop a reasonable financial assurance framework for mine closure. Some initiatives are already underway to address these challenges such as the formulation of regulations and sector guidelines under the Environmental Impact Assessment Act, Promulgation of the Environmental Management Act and capacity building under the Environment Support Programme. 


\section{BACKGROUND}

Mining forms the backbone of the economy of Botswana contributing about a third of Gross Domestic Product, over $40 \%$ of Government revenues and about three quarters of export earnings. The major portion of the mining contribution is due to diamonds. However, there are other large scale mining operations which are significant contributors to the socio-economic situation in Botswana.

With such an important socio-economic contribution to the country it is imperative that mine closures are well planned and executed to minimise adverse socio-economic impacts.

Botswana has the following large scale mining operations:

- Three Diamond mines - At Jwaneng, Orapa and Letlhakane owned by Debswana Diamond Company.

- Two Copper-nickel mines - one owned by BCL Limited and the other by Tati Nickel Mining Company.

- One Colliery - owned by Morupule Colliery Limited.

- One Soda ash-salt mine - owned by Botswana Ash (Pty) Ltd.

The commissioning of these mines ranges from the period early 1970s to early 1990s. The country has no experience of dealing with closure of large mines. The only significant mine rehabilitation issues that the Department of Mines, which is a technical department dealing with environmental issues related to mining (including mine closures) has dealt with is rehabilitation of abandoned old mine workings. They are predominately shafts from the gold rush era of the nineteenth century. Closure of large mines will be larger in scale and complexity in comparison and will therefore be more challenging.

One copper-nickel mine is likely to close in the next decade. Work has already begun in preparing for the closure of the mine. A preliminary mine closure plan has been prepared and has been circulated to relevant stakeholders. Other mines are at various stages of formulation of mine closure plans with at least two preliminary closure plans having been prepared.

One of the important principles in conducting mining operations is to plan with the end in mind. Knowledge of closure issues particularly environmental ones were largely absent at the inception of these mines such that closure objectives were not built into mining planning in the early years of operations.

\section{LEGAL CONTEXT}

Legislation relevant to mine closure in Botswana is still evolving and is still not yet adequate for purpose. In fact there are no specific or prescriptive requirements under the various Acts dealing with mine closure. Even where there is reference or inference to mine closure there are no adequate regulations or guidelines to guide the mining companies in the formulation of mine closure plans.

Listed below is relevant legislation to mine closure and the relevance is explained in Table 1 which follows.

- Mines and Minerals Act (Cap 66:01 of the Laws of Botswana).

- Mines, Quarries, Works and Machinery Act (Cap 44:02 of the Laws of Botswana).

- Environmental Impact Assessment Act, Act No.6 of 2005.

- Waste Management Act (Cap 65:06 of the Laws of Botswana).

- Tribal Land Act (Cap 32:02 of the Laws of Botswana).

- Monuments and Relics Act (Cap 59:03 of the Laws of Botswana).

- Employment Act (Cap 47:01 of the Laws of Botswana). 
Table 1 Relevant legislation to mine closure

\begin{tabular}{|c|c|c|}
\hline $\begin{array}{l}\text { Name of the } \\
\text { Act }\end{array}$ & Relevance to Mine Closure & Relevant Provisions \\
\hline $\begin{array}{l}\text { Mines and } \\
\text { Minerals Act }\end{array}$ & $\begin{array}{l}\text { Deals with matters of progressive } \\
\text { rehabilitation and mine closure }\end{array}$ & $\begin{array}{l}\text { Section } 65 \text { deals with rehabilitation and } \\
\text { reclamation of mine sites }\end{array}$ \\
\hline $\begin{array}{l}\text { Mines, } \\
\text { Quarries, } \\
\text { Works and } \\
\text { Machinery Act }\end{array}$ & $\begin{array}{l}\text { Deals with Mine Safety, Health and } \\
\text { Environmental matters during pre- } \\
\text { production, operational and } \\
\text { decommissioning phases }\end{array}$ & $\begin{array}{l}\text { Regulation } 215 \text { deals with duties of a holder on } \\
\text { lapse of mineral concession }\end{array}$ \\
\hline $\begin{array}{l}\text { Environmental } \\
\text { Impact } \\
\text { Assessment Act }\end{array}$ & $\begin{array}{l}\text { Deals with broader issues of } \\
\text { environment impact statements }\end{array}$ & $\begin{array}{l}\text { Section } 9 \text { deals with the requirement for an } \\
\text { Environmental Impact Statement (EIS) } \\
\text { Section } 10 \text { Content of an EIS } \\
\text { Section } 20 \text { Monitoring and Evaluation } \\
\text { Section } 21 \text { Auditing }\end{array}$ \\
\hline $\begin{array}{l}\text { Waste } \\
\text { Management } \\
\text { Act }\end{array}$ & $\begin{array}{l}\text { Deals with management of general } \\
\text { waste and hazardous waste }\end{array}$ & $\begin{array}{l}\text { Part VI deals with registration of waste } \\
\text { disposal sites and licensing of waste } \\
\text { management facilities }\end{array}$ \\
\hline Tribal Land Act & $\begin{array}{l}\text { Deals with issues of land use planning } \\
\text { and allocation in tribal territories }\end{array}$ & $\begin{array}{l}\text { Section } 17 \text { deals with land use zones } \\
\text { Section } 38 \text { deals with the transfer of rights }\end{array}$ \\
\hline $\begin{array}{l}\text { Monument and } \\
\text { Relics Act }\end{array}$ & $\begin{array}{l}\text { Deals with preservation of sites of } \\
\text { archaeological and cultural } \\
\text { significance }\end{array}$ & $\begin{array}{l}\text { Section } 9 \text { deals with agreements for the } \\
\text { preservation of monuments, artifacts and } \\
\text { protected heritage areas } \\
\text { Section } 10 \text { Declaration of National Monuments } \\
\text { Section } 11 \text { Declaration of recent historic } \\
\text { monuments }\end{array}$ \\
\hline $\begin{array}{l}\text { Employment } \\
\text { Act }\end{array}$ & $\begin{array}{l}\text { Deals with employment conditions } \\
\text { including terminal benefits for } \\
\text { employees }\end{array}$ & $\begin{array}{l}\text { Part III deals with Contracts of Employment } \\
\text { and Part VI which deals with Protection of } \\
\text { Wages }\end{array}$ \\
\hline
\end{tabular}

\section{STAKEHOLDER EXPECTATIONS}

With regards to mine closure there are essentially four key stakeholder groups whose expectations have to be met. These are the authorities, Employees, communities and shareholders. Their needs will have to be embedded into the mine closure process (planning and implementation). Table 2 below gives a summary of minimum expectation of these stakeholder groupings. These expectations form the basis of the mine closure objectives.

The minimum requirements for closure are normally captured by legislation and therefore can be met through compliance. However, it is prudent for a mining company to look beyond compliance. A mining company should aim for a high level of Corporate Social Responsibility (CSR) even when it is winding up its operations. The social responsibilities will largely not be defined by legislation but by the purpose and values of the organisation. A company should endeavour to use the best available techniques or best practice in planning and execution of mine closure. 
Table 2 Minimum expectations of key stakeholders for mine closure

\begin{tabular}{|c|c|c|c|c|}
\hline & \multicolumn{4}{|c|}{ Stakeholders } \\
\hline Expectations & Authorities & Employees & Communities & Shareholders \\
\hline $\begin{array}{l}\text { Mine site(s) not } \\
\text { abandoned. }\end{array}$ & $\sqrt{ }$ & $\sqrt{ }$ & $\sqrt{ }$ & $\sqrt{ }$ \\
\hline $\begin{array}{l}\text { Site(s) rehabilitated to } \\
\text { original state or for } \\
\text { alternative use(s). }\end{array}$ & $\sqrt{ }$ & & $\sqrt{ }$ & \\
\hline $\begin{array}{l}\text { Site(s) made safe (for } \\
\text { human and animals). }\end{array}$ & $\sqrt{ }$ & $\sqrt{ }$ & $\sqrt{ }$ & $\sqrt{ }$ \\
\hline $\begin{array}{l}\text { Site(s) physically, } \\
\text { chemically and } \\
\text { biologically stable. }\end{array}$ & $\sqrt{ }$ & & $\sqrt{ }$ & $\sqrt{ }$ \\
\hline $\begin{array}{l}\text { Residual impacts } \\
\text { acceptable and without } \\
\text { significant deterioration } \\
\text { over time. }\end{array}$ & $\sqrt{ }$ & & $\sqrt{ }$ & $\sqrt{ }$ \\
\hline $\begin{array}{l}\text { Closure achieved with } \\
\text { efficiency and cost- } \\
\text { effectiveness. }\end{array}$ & & & & $\sqrt{ }$ \\
\hline $\begin{array}{l}\text { Adverse socio-economic } \\
\text { impacts due to closure } \\
\text { minimized. }\end{array}$ & $\sqrt{ }$ & $\sqrt{ }$ & $\sqrt{ }$ & \\
\hline $\begin{array}{l}\text { Mining company released } \\
\text { from post closure } \\
\text { environmental liability } \\
\text { (walk-away). }\end{array}$ & & & & $\sqrt{ }$ \\
\hline $\begin{array}{l}\text { Terminal benefits are } \\
\text { paid out. }\end{array}$ & & $\sqrt{ }$ & & \\
\hline
\end{tabular}

\section{MINE CLOSURE ISSUES/CHALLENGES}

The main challenges in the formulation and execution of mine closure plans for large mines in Botswana are:

- Inadequacy of environmental legislation to guide the mining companies in closure matters.

- Inadequacy of environmental expertise to guide the mine closure process from planning to final rehabilitation.

- Meeting approval requirements of the authorities for the mine closure plans. 
- Gaining acceptance of the communities for the mine closure plans.

- Sustainability of Social Investment Program beyond the life of mining operations.

- Preservation of a positive legacy.

\subsection{Inadequacy of Legislation}

The lack of specific or prescriptive provisions in the Botswana legislation or guidelines for dealing with mine closure is a challenge for mining companies. This is a challenge as there is very little to guide them in the mine closure planning phase. This has a potential to add to the time and cost of planning.

Section 65 of the Mines and Minerals Act deals with environmental obligations of mine proponents. S 65 (1) states that "The holder of a mineral concession shall, in accordance with the law in force from time to time in Botswana and in accordance with good mining industry practice, conduct his operations in such a manner as to preserve in as far as possible the natural environment, minimize and control waste or undue loss or damage to natural and biological resources...". Currently there are no regulations, standards or approved guidelines to define what constitute good mining industry practice. S 65 (3) states that "The holder of a mineral concession shall ensure that his concession area is rehabilitated from time to time and ultimately reclaimed in so far as is practicable in a manner acceptable to the Director of Mines". Currently there are no regulations, standards or guidelines to underpin this subsection. S 65 (9) states that "The holder of a mineral concession shall make adequate ongoing financial provision for compliance with his obligations under this section (S 65)". There is no finance assurance framework to underpin this provision of the Act.

Regulations 213 and 215 of the Mines, Quarries, Works and Machinery Act deal with the protection of abandoned excavation and shafts and duties of the holder on lapse of mineral concession respectively.

The Environmental Impact Assessment Act which is the only Act in Botswana specifically dealing with the broader issue of environment requires developers to prepare environmental impact statements for their projects but does not have specific provisions dealing with closure matters.

\subsection{Inadequacy of Environmental Expertise}

Mainstreaming of environmental issues is a relatively new phenomenon in Botswana. Local expertise in the field of environment is grossly inadequate to meet the national needs. Therefore, the mining companies are reliant on imported expertise for which they have to pay a premium and the expertise is not necessarily readily available when required.

\subsection{Meeting Approval Requirements of Authorities}

To get approval of relevant authorities it is imperative that the proponent demonstrate that the proposed closure objectives are reasonable and the methods of attaining the objectives are feasible.

From the view point of the authorities, based on the Polluter Pays and Precautionary principles, they are likely to error on the side of caution rather than giving the mining company the benefit of the doubt. They will aim to eliminate or reduce to minimal the risk of transferring any future environmental liability from the mining company to the authorities or community.

It may be prudent for the proponents to pilot some of the methods that they plan to use for final rehabilitation to demonstrate that they will work for final closure and thus give comfort to the authorities and other stakeholders.

\subsection{Gaining Acceptance of Communities}

It is important that there is a buy-in to the mine closure plan by the community as they are the ones who have to live with any residual impacts. The challenge for a mining company is acceptance by the community of the closure objectives as being reasonable. 


\subsection{Sustainability of the Social Investment Programs}

Large mining companies in Botswana has made a variety of social investments including those in housing, schools, clinics, hospitals, roads and wellness programs for employees and their dependents. Some of the facilities such as hospitals, even though they are fully funded by the mining companies, are open to the communities. Therefore, it is a challenge as to how they will be sustained post mining.

\subsection{Preservation of Legacy}

Modern mining has a healthy legacy in Botswana. Mining companies have been partners in development to the Government of Botswana. The companies have been at the forefront of skills development, infrastructure development such as schools and health facilities.

It is this positive legacy that they would wish to retain. Therefore, it is a challenge for mining companies to preserve the positive legacy into the post closure period.

\section{WAY FORWARD/RECOMMENDED ACTION}

\subsection{Development of Environmental Expertise}

Large mining companies have a crucial role to play in the development of environmental expertise beyond merely developing for their own needs. They should facilitate the development of expertise for the nation.

Their role in this endeavour may include:

- Giving opportunities for practical training for third parties such as internships, internal and external auditing opportunities of the Environmental Management Systems for local professionals.

- Assisting with formulation of training courses relevant to environmental management.

- Active participation in the development of standards pertaining to mine closure and environmental management in general.

\subsection{Development of Standards, Guidelines and Codes of Best Practice}

Lack of specific legislation dealing with mine closure issues does not bar mining companies from doing the right thing. There is enough information/literature available on best practices that mining companies can adapt in the absence of legislation. In any case legislation would only prescribe minimum requirements and not necessarily best practices. So even in the presence of adequate legislation mining companies have a moral duty to keep themselves informed on best practices and best available technologies such that they can adapt them to their mine closure planning and execution. Mining companies can use existing structure such as the Chamber of Mines and Bureau of Standards as vehicles for developing Standards, Guidelines and Codes of Best Practice.

It is suggested that the companies adopt the Sustainable Development Framework to assist them with their overall environmental management programs including mine closure plans. The Sustainable Development Framework will give an assurance that during the life cycle of a mining project the planning is informed by the ultimate closure objectives. Mine planning should take care of the cradle to grave issues.

It is also recommended that companies develop and install Environmental Management Systems (EMS) that comply with international standards such as ISO 14001. This will give assurance to authorities and communities of company's compliance to international standards and norms in environmental management. So far only the diamond mines in Botswana are ISO 14001 certified, for other mines the establishment of EMS is generally work-in-progress.

\subsection{Gaining Acceptance of Closure Plan by the Community}

One of the critical objectives of mine closure is acceptance of closure plan by local community. Such acceptance should be based on informed choice rather than ignorance. The communities have a right to be informed and to be heard if mine closure plans have to gain their acceptance. It will greatly assist if 
communities are represented in consultative forums and decision making structures dealing with mine closure.

\subsection{Sustainability of Social Investment Programs}

In Botswana social investment programs by large mines have been generous. They have also typically been embedded within the company structures. They are not autonomous from the mining operations and thus are unlikely to survive beyond the life of mining operations.

It is suggested that autonomous bodies be established to run social investment programs on behalf of mining companies. This will enhance chances of sustainability beyond mining operations and facilitate access to resources beyond those of the mining companies. An example of a model that can be adopted is the Mozal Community Development Trust (MCDT) in Mozambique. MCDT was created in August 2000 by the shareholders of Mozal and has been fully operational since January 2001. The formation of MCDT has been guided by principles of Sustainable Development. It has a Board of Trustees and its activities cover five key development areas.

- Small Business Development.

- Education and Training.

- Health and Environment.

- Sports and Culture.

- Community Infrastructures.

Other than the Small Business Development initiative which is only being pursued by Debswana Diamond Company, the other areas are pursued by all the large mining companies in Botswana. The major difference to that of Mozal is lack of autonomy and lack of integration of the various social investment programs.

\subsection{Preservation of a Positive Legacy}

As a corporate citizen a mining company has legal and moral obligations to ensure that the negative impacts of mine closure are minimised. To enhance the chances of this closure objective being met it is critical that the closure plan is integrated with both the environmental and social aspects fully addressed. Plans to address the environmental aspects will be predominantly for implementation by the proponent (mining company) but the social plan while it should be initiated by the mining company requires eventual ownership of other stakeholder at the post closure phase.

Therefore, it is imperative that key stakeholders such as relevant authorities, communities and labour are intimately involved with the mine closure process such that they own the process and eventual outcomes of mine closure. Companies have to take a deliberate effort to involve the relevant stakeholders and to make the process as transparent as possible to interested and affected parties.

The design criteria for mine closure are critical and the options are:

- Walk-away.

- Passive care.

- Active care.

A walk-away solution is whereby no additional monitoring or maintenance is required after rehabilitation. Passive care is whereby there is minimal ongoing need for occasional monitoring and infrequent minor maintenance. Active care is whereby there is a requirement for ongoing operation, maintenance and monitoring of the rehabilitated site.

The walk-away solution represents ideally the best option that a mining company can select as it has the lowest time liability for the proponent and has the lowest risk of residual impacts. Therefore, it has a better chance of acceptance by the authorities and community. A rehabilitated site will not be considered closed out till such time the conditions for walk-away are met. 


\subsection{Initiatives by the Authorities}

It is apparent from the stated challenges faced by mining companies that authorities have related challenges of their own. There is a need for the authorities to:

- Expeditiously develop and consolidate legislation relevant to mine closure. Some work has already commenced with the following initiatives underway:

- Formulation of Regulations and Sector Guidelines under the Environmental Impact Assessment Act

- Promulgation of the Environmental Management Act.

- Formulation of Regulations under the Mines and Minerals Act.

- Drafting of Mine Closure Standards/Guidelines to give effect to Subsection 65 (3) of the Mines and Minerals Act.

- Build capacity to deal effectively with environmental management issues in general including mine closure.

- A three year Environment Support Programme between the United Nation Development Program and the Government of Botswana which includes capacity building is ongoing.

- Develop a reasonable framework for financial assurance for mine closure.

\section{CONCLUSION}

Large mining companies in Botswana have been good corporate citizens and staunch partners to government in the development of the country. It is accepted that mining has a finite life and mining companies are challenged to properly plan for and execute mine closures to preserve this positive legacy. The mine closure plans should integrate both the environmental and social needs if they are to be effective.

The authorities also have a challenge to expeditiously develop and consolidate the relevant legislation, develop capacity to effectively deal with mine closures and develop a reasonable financial assurance framework for mine closure.

\section{REFERENCES}

Berlin II Guidelines for Mining and Sustainable Development, United Nations (2002).

Environmental Impact Assessment Act, Act No. 6 of 2005, Botswana Government Printer.

Employment Act (Cap 47:01 of the Laws of Botswana), Act No. 14 of 2003, Botswana Government Printer.

Good Practice Guidance for Mining and Biodiversity, ICMM (2006).

ICMM Sustainability Development Framework, ICMM (2003).

Mine Closure Guidelines for Minerals Operations in Western Australia, Chamber of Minerals and Energy of Western Australia Inc (2000).

Mines and Minerals Act (Cap 66:01 of the Laws of Botswana), Act No. 17 of 1999, Botswana Government Printer.

Mines, Quarries, Works and Machinery Act (Cap 44:02 of the Laws of Botswana), Act No. 15 of 1995, Botswana Government Printer.

Monuments and Relics Act (Cap 59:03 of the Laws of Botswana), Act No. 12 of 2001, Botswana Government Printer.

Principles for the Conduct of Company Operations within the Minerals Industry, Australian Non-Government Organisations (1998).

Waste Management Act (Cap 65:06 of the Laws of Botswana), Act No. 15 of 1998, Botswana Government Printer.

Reporting against the ICMM Sustainable Development Principles, ICMM (2005).

Tribal Land Act (Cap 32:02 of the Laws of Botswana), Act No. 1 of 2003, Botswana Government Printer. 